\title{
Article
}

\section{Water Quality Assessment and Evaluation of Human Health Risk in Mutangwi River, Limpopo Province, South Africa}

\author{
Rofhiwa T. Madilonga $^{1}\left(\mathbb{D}\right.$, Joshua N. Edokpayi ${ }^{1, * \mathbb{D}}$, Elijah T. Volenzo ${ }^{1} \mathbb{D}$, Olatunde S. Durowoju $^{1} \mathbb{D}$ \\ and John O. Odiyo ${ }^{1,2}$ \\ 1 Department of Hydrology and Water Resources, University of Venda, Thohoyandou 0950, South Africa; \\ madilongarofhiwateresa@gmail.com (R.T.M.); volenztom@gmail.com (E.T.V.); \\ olatunde.durowoju@univen.ac.za (O.S.D.); johno@vut.ac.za (J.O.O.) \\ 2 Office of the DVC Research Innovation Commercialization and Internationalization (RICI), \\ Vaal University of Technology, Vanderbijlpark 1911, South Africa \\ * Correspondence: Joshua.Edokpayi@univen.ac.za
}

check for updates

Citation: Madilonga, R.T.; Edokpayi, J.N.; Volenzo, E.T.; Durowoju, O.S.; Odiyo, J.O. Water Quality Assessment and Evaluation of Human Health Risk in Mutangwi River, Limpopo Province, South Africa. Int. J. Environ. Res. Public Health 2021, 18, 6765. https://doi.org/10.3390/ ijerph18136765

Academic Editor: Paul B. Tchounwou

Received: 14 May 2021

Accepted: 15 June 2021

Published: 24 June 2021

Publisher's Note: MDPI stays neutral with regard to jurisdictional claims in published maps and institutional affiliations.

Copyright: (c) 2021 by the authors. Licensee MDPI, Basel, Switzerland. This article is an open access article distributed under the terms and conditions of the Creative Commons Attribution (CC BY) license (https:/ / creativecommons.org/licenses/by/ $4.0 /)$.

\begin{abstract}
Freshwater supply is essential to life on Earth; however, land use activities such as mining and agriculture pose a significant danger to freshwater resources and the wellbeing of aquatic environments. This study temporarily assesses the water quality characteristics of Mutangwi River. Physicochemical parameters ( $\mathrm{pH}$, temperature, total dissolved solids (TDS), salinity, electrical conductivity (EC), and turbidity) were determined in situ using an Extech multimeter and turbidity meter. The concentration of the selected metals $(\mathrm{Mg}, \mathrm{Cr}, \mathrm{Fe}, \mathrm{Cd}, \mathrm{Mn}, \mathrm{Pb}, \mathrm{Ca}$, and $\mathrm{Na}$ ) were analysed using an Atomic Absorption Spectrophotometer. Membrane filtration method was used to analyse microbiological parameters (Escherichia coli and Enterococci). The physicochemical water quality parameters as well as basic anions (fluoride, phosphate, sulfate, nitrate, and chloride) determined complied with the regulatory guideline of the World Health Organization (WHO) and the South Africa National Standards (SANS). Some of the trace metals ( $\mathrm{Mn}, \mathrm{Ca}, \mathrm{Fe}$, and $\mathrm{Mg}$ ) were found below the guideline values, while others $(\mathrm{Pb}$ and $\mathrm{Cd}$ ) exceeded the threshold limit. The counts for E. coli $(814.5-2169 \mathrm{cfu} / 100 \mathrm{~mL})$ and Enterococci (333-9396 cfu/100 mL) in the study did not comply with the regulatory guidelines. The water quality status using the water quality index (WQI) indicated that on the average, the water quality from Mutangwi River is poor (WQI > 100). The hazard quotient through ingestion exposure did not exceed the threshold limit of 1 , for adults and children. This implies that there is no potential non-carcinogenic health risk from trace elements via ingestion of drinking water for children and adults. However, cancer risk for adults and children was computed in relation to $\mathrm{Cd}$ and $\mathrm{Pb}$ levels and exceeded the threshold limit $10^{-4}$, indicating a possible carcinogenic risk. Water from the river should be adequately treated prior to domestic and agricultural use.
\end{abstract}

Keywords: land use activities; Mutangwi River; water quality; E. coli; carcinogenic risk; water quality index

\section{Introduction}

Water quality often determines the fitness of water use for a variety of purposes. The assessment of water quality is thus important to evaluate the water use potential of any water resource [1]. The consumption of clean and safe water has been linked to increased health outcomes globally [2,3]. Despite the achievements that have been recorded with increased access to potable water, millions of people suffer various health-related preventable diseases due to the consumption of contaminated water [4].

In many cities and towns globally, sustainable access to clean and safe water has been reported; however, unfortunately, many people who live in peri-urban and rural regions of the world do not have continuous access to clean and safe water and they often resort to several alternative sources for their domestic water needs [5-9]. In most low-income countries, water is usually abstracted from rivers, lakes, and dams and used without any 
form of treatment $[10,11]$. The ease of access to surface water is one of the controlling factors contributing to its wide use, though it is often prone to higher chances of contamination and serves as one of the major sinks for environmental pollution $[10,12]$. Water quality is of a great concern globally because the decline in its quality due to contamination has great economic and public health burden $[5,7,10]$.

In South Africa, surface waters such as rivers, lakes, ponds, and streams are key components for water supply due to the numerous dams that are fed from them. In the absence of sustainable access to potable water in rural areas, people are left to seek for alternative sources to meet their basic needs, and surface water is the first point of call as it is easy to access and use $[2,3,11]$. Consumption of untreated and inadequately treated water remains a major disease burden to public health and causes waterborne diseases such as cholera, typhoid, and dysentery [10,12]. Furthermore, high levels of trace metals and anions in drinking surface water have been reported to cause various health complications, including gastric cancer, baby blue syndrome, altered reproduction potential, and mouth ulceration $[13,14]$.

Anthropogenic and natural factors can cause an increase in the level of contamination of freshwater sources $[8,15]$. Activities such as human settlements, industrialization, and agriculture (crop and livestock farming) have adversely affected the quality of most rivers, streams, and dams. Although there are legislations to protect surface water bodies from pollution, such as the pollutant pay principle, they are hardly enforced [5]. This has consequently led to increased contamination of surface water bodies, which are often a source of domestic water, agricultural water, occupation, and recreation to many who lives along their course [9].

Mutangwi River is widely used for domestic, recreational, and agricultural purposes (irrigation and animal watering). Moreover, small-scale businesses such as car washes abstract water from the river. Small-scale fishing also occurs within the river course. Edokpayi et al. [12] reported the discharge of inadequately treated hospital wastewater effluent into the river before it joins the Nzhelele River, which feeds the Nzhelele dam for water supply. Other potential sources of pollution to the river system include open dumping of solid wastes, open grazing of free-ranging animals, and surface runoff from various farmlands within its course. Hence, it is of outmost importance to report on the water quality status of Mutangwi River as, to the best of our knowledge, there are no published data on this important water resource in a semi-arid region of South Africa.

We, therefore, report our findings on the physicochemical and microbiological characteristics of Mutangwi River. In addition, we present the overall status of water in the river using the Water Quality Index (WQI), which is a versatile tool for summarizing the water quality status of a river system. Furthermore, since the water is used for several purposes, we computed the potential carcinogenic and noncarcinogenic health risk associated with its consumption based on the trace metals levels recorded.

\section{Materials and Methods}

\subsection{Study Area}

The study area is situated at Mudunungu Village, Thulamela Municipality. It is located at a height of $1318 \mathrm{~m}$ above the sea level. Its geographical location is $22^{\circ} 52^{\prime} 60^{\prime \prime} \mathrm{S}$ and $30^{\circ} 13^{\prime} 0^{\prime \prime}$ E. Mutangwi River (Figure 1 ) is generally used for various activities but mainly for domestic and agriculture purposes (Thulamela Municipality IDP Review, 2013-2014). It is estimated that about $80 \%$ of rainfall is received in summer (September-March) compared to the winter period (April-August). Daily temperature in the catchment ranges between 12 and $22{ }^{\circ} \mathrm{C}$ in the dry season and between 20 and $41{ }^{\circ} \mathrm{C}$ during the wet season [16].

The mean yearly precipitation ranges from 480 to $560 \mathrm{~mm}$, with a mean annual runoff of about 50 million cubic meters [16].

The potential pollution sources include ablution facilities, sanitation, car wash, laundry, and dumping of refuse on open spaces and on the riverbank. Land use activities vary in the upper, middle and lower parts of Mutangwi River. The river is covered by large-scale 
agricultural activities, there is dominant forest in the upper stream and the lower part has cropping plantation.

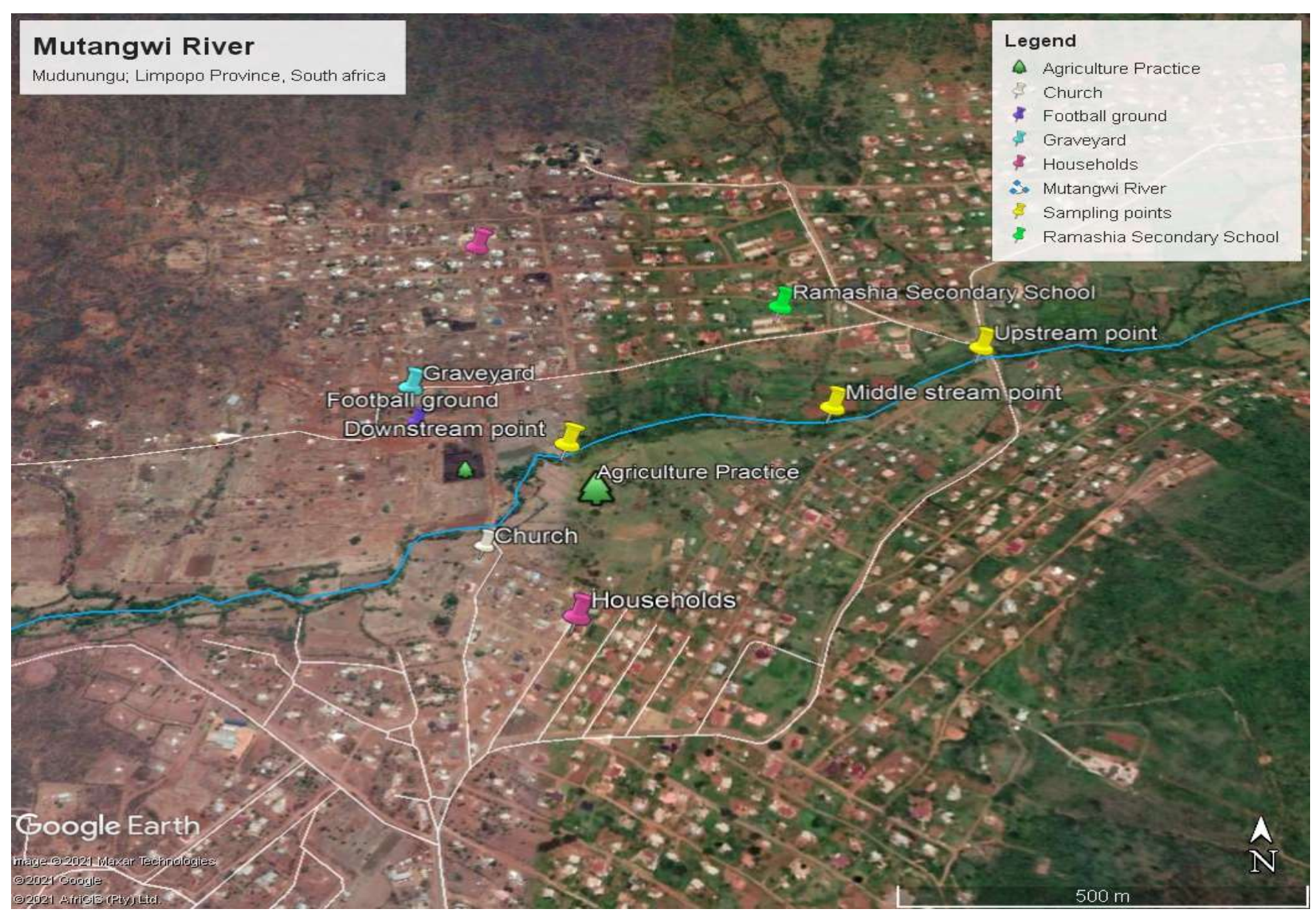

Figure 1. Map of the study area.

\subsection{Sampling}

Mutangwi River was divided into three sections, which are the upstream, midstream, and downstream, for samples collection. Twenty-seven water samples were collected in triplicate using sterilized plastics bottles on a monthly basis between June and August 2018. Samples were collected for physicochemical, microbiological, and trace metals analyses. Water samples for metals were preserved with concentrated nitric acid. Collected samples were kept in an ice chest and transported to the Hydrology Laboratory of the University of Venda for further examination. Microbial analysis was performed within $6 \mathrm{~h}$ of sample collection.

\subsection{Samples Analysis}

2.3.1. Physiochemical Parameters

Temperature, $\mathrm{pH}$, electrical conductivity (EC), salinity, and total dissolved solids (TDS) were measured in the field using an Extech multimeter (EC 400, Extech Instruments, Nashua, NH, USA). Turbidimeter was used to measure the turbidity (TB 400, Extech Instruments, Nashua, $\mathrm{NH}$, USA) of the water samples.

\subsubsection{Trace Metals}

Trace metals were analysed using an atomic absorption spectrophotometer $(900 \mathrm{H}$, Perkin Elmer, Akron, OH, USA). Calibration standards were prepared from $100 \mathrm{mg} / \mathrm{L}$ stock solution of the test metals. 


\subsubsection{Anions}

Anion (fluoride, phosphate, sulphate, nitrate, and nitrite) concentrations were determined using Ion Chromatography (IC). The water samples were filtered with syringe filters $(0.45 \mu \mathrm{m})$ and placed in a standard vial in an automated autosampler connected to the IC (850 professional IC, Metrohm AG, Herisau, Switzerland).

\subsubsection{Microbiological Analysis}

Escherichia coli and Enterococcus levels in the samples were evaluated using Membrane Filtration (MF) technique. M-Tec Chromo select Agar (Sigma Aldrich, Johannesburg, South Africa) was prepared for E. coli enumeration while m-Enterococcus Agar (Sigma Aldrich, Johannesburg, South Africa) was used for the determination of enterococci levels. The agars were prepared according to the manufacturer's guidelines. The samples $(100 \mathrm{~mL})$ were filtered through $47 \mathrm{~mm}$ sterile membrane filters using a vacuum pump and a manifold by adhering to the protocols of the American Public Health Association [17]. The filter paper containing the test organisms was incubated for 24 and $48 \mathrm{~h}$ at $37^{\circ} \mathrm{C}$ and $45^{\circ} \mathrm{C}$ for E. coli and enterococci, respectively. The results were reported as colony-forming units per $100 \mathrm{~mL}$ of sample.

\subsection{Water Quality Index (WQI)}

WQI is an index that reflects the composite impact of various water quality parameters for easy interpretation and use by water administrators. The WQI was computed through three steps. First, each of the 15 parameters was assigned a weight $\left(w_{i}\right)$ according to their relative importance in the overall quality of water for drinking purposes (Table 1 ). The maximum weight of 5 was assigned to a parameter because of its major importance in water quality assessment, minimum weight of 1 was assigned to those parameters deemed insignificant to the overall water quality. Other parameters were assigned weights between 1 and 5 based on their relative significance in the water quality evaluation. The mathematical formula used for the WQI computation is presented in the equations below $[18,19]$ :

$$
W i=\frac{w i}{\sum_{i=1}^{n} w i}
$$

$W i$ is the unit weight of pollutant variable; $n$ is the total number of pollutant variables; $w i$ is the weight of each parameter.

$$
\text { Quality rating scale }(q i)=\left(\frac{C i}{S i}\right) \times 100
$$

$q i$ is the quality rating, $C i$ is the concentration of each chemical parameter in each water sample in $\mathrm{mg} / \mathrm{L}$, and $S i$ is the drinking water standard for each chemical parameter in $\mathrm{mg} / \mathrm{L}$.

Table 1. Water quality rating based on WQI.

\begin{tabular}{lllc}
\hline WQI & Quality Status & Possible Use & Grading \\
\hline 50 & Excellent water quality & Domestic purposes & A \\
$50-100$ & Good water quality & Any purpose without treatment & B \\
$100-200$ & Poor water quality & Irrigation and partial body contact & C \\
$200-300$ & Very poor water quality & Irrigation and industrial, domestic & D \\
$>300$ & Unsuitable for drinking purposes & Proper treatment required before use & E \\
\hline
\end{tabular}


For computing WQI, $q i$ and $W i$ were used as shown in Equation (3) below $[18,19]$.

$$
\mathrm{WQI}=\sum_{i=1}^{n} W i \times q i
$$

WQI ranks water quality in the range of excellent to unsuitable for drinking with numerical values computed using Equation (3) (Table 1).

\subsection{Quantitative Health Risk Assessment}

Human exposure risk pathways of an individual to trace metals contamination could be through three main pathways including inhalation via nose and mouth, direct ingestion, and dermal absorption through skin exposure. Common exposure pathways to water are dermal absorption and ingestion routes. Exposure dose for determining human health risk through these two pathways has been described in the literature [21] and can be calculated using the equations below:

$$
\begin{gathered}
\text { Expingestion }=\frac{C_{\text {water }} \times I R \times E F \times E D}{B W \times A T} \\
\text { Exp }_{\text {dermal }}=\frac{C_{\text {water }} \times S A \times K p \times E T \times I R \times E F \times E D \times C F}{B W \times A T}
\end{gathered}
$$

where $\operatorname{Exp}_{\text {ingestion }}$ is the exposure dose through ingestion of water $\left(\mathrm{mg} / \mathrm{kg} /\right.$ day); $\operatorname{Exp}_{\text {dermal }}$ is the exposure dose through dermal absorption ( $\mathrm{mg} / \mathrm{kg} /$ day); $C_{\text {water }}$ is the average concentration of the estimated metals in water $(\mu \mathrm{g} / \mathrm{L})$, and $K p$ is the dermal permeability coefficient in water (cm/h): 0.001 for $\mathrm{Cu}, \mathrm{Mn}, \mathrm{Fe}$, and Cd, while 0.0006 for $\mathrm{Zn}, 0.002$ for $\mathrm{Cr}$, and 0.004 for $\mathrm{Pb}$. The other constants in those equations are shown in Table 2.

Table 2. Health risk assessment of different exposure through parameter.

\begin{tabular}{lccc}
\hline \multicolumn{1}{c}{ Parameter } & Unit & Child & Adult \\
\hline Exposure Frequency (EF) & Day/year & 365 & 365 \\
Body Weight (BW) & $\mathrm{kg}$ & 15 & 70 \\
Ingestion Rate (IR) or Daily intake (DI) & $\mathrm{L} /$ day & 1.8 & 2.2 \\
Exposure Duration (ED) & Years & 6 & 70 \\
Skin surface Area (SA) & $\mathrm{cm}^{3}$ & 6600 & 18,000 \\
Exposure Time (ET) & Hours $/$ day & 1 & 0.58 \\
Conversion Factor (CF) & $\mathrm{L} / \mathrm{cm}^{3}$ & 0.001 & 0.001 \\
Averaging Time (AT) & Days & $365 \times 6$ & $365 \times 70$ \\
Particular Emission Factor (PEM) & $\mathrm{m}^{3} / \mathrm{kg}$ & $1.3 \times 10^{9}$ & $1.3 \times 10^{3}$ \\
\hline
\end{tabular}

Adapted from [21].

Potential noncarcinogenic risks due to exposure of trace metals were determined by comparing the calculated contaminant exposures from each exposure route (ingestion and dermal) with the reference dose ( $R f D$ ). The constant of $R f D_{\text {ingestion }}$ of $\mathrm{Cd}, \mathrm{Pb}, \mathrm{Mn}$, and $\mathrm{Fe}$ is $0.5,1.4,24$, and 700 , respectively, while $R f D_{\text {dermal }}$ values of analysed trace elements $C \mathrm{~d}, \mathrm{~Pb}$, $\mathrm{Mn}$, and Fe are $0.025,0.42,0.96$, and 140 [21]. The Hazard Quotient $(H Q)$ toxicity potential of an average daily intake to reference dose for an individual via the two pathways can be determined using Equation (6) [22].

$$
H Q_{\text {ingestion } / \text { dermal }}=\frac{\text { Exp } p_{\text {ingestion } / \text { dermal }}}{R f D_{\text {ingestion } / \text { dermal }}}
$$

where $R f D_{\text {ingestion/dermal }}$ is ingestion/dermal toxicity reference dose $(\mathrm{mg} / \mathrm{kg} /$ day). The $R f D_{\text {ingestion/dermal }}$ values were obtained from the literature $[18,21,23]$. An $\mathrm{HQ}<1$ is assumed to be safe and taken as significant noncarcinogenic [24], but HQ $>1$ indicates a potential health risk to those exposed to the levels of the contaminant. 
To assess the overall potential noncarcinogenic effects posed by more than one metal and pathway, the sum of the computed HQs across metals was expressed as hazard index (HI) [21]. HI > 1 showed that exposure could have a potential adverse effect on human health [18].

Carcinogenic risk $(C R)$ through ingestion pathway was estimated using Equation (7):

$$
C R_{\text {ingestion }}=\text { Exp }_{\text {ingestion }} \times C S F
$$

where $C R_{\text {ingestion }}$ is cancer risk through ingestion of trace metals-contaminated water, Expingestion is average daily dose ( $\mathrm{mg} / \mathrm{kg} /$ day) of heavy metals, and CSF is cancer slope factor $(\mathrm{mg} / \mathrm{kg} /$ day). The slope factor for $\mathrm{Pb}$ and $\mathrm{Cd}$ is 0.009 and 6.1, respectively.

\section{Results and Discussion}

\subsection{Physical Parameters}

The EC values ranged from 182.25 to $233.17 \mu \mathrm{S} / \mathrm{cm}$ (Table 3). The values recorded complied with the standard guideline of $<1700 \mathrm{mS} / \mathrm{m} \mathrm{[25]} \mathrm{and} 600 \mathrm{mS} / \mathrm{m}$ [26], respectively. The average values of TDS ranged from 126.37 to $167.5 \mathrm{mg} / \mathrm{L}$, and were numerically higher in downstream sites (Table 3 ) and complied with regulatory standards.

Temperature plays a crucial role in water bodies with regards to chemical responses and the metabolic rates of life forms and it is therefore a controlling factor of aquatic species distribution $[27,28]$. Mean temperatures recorded in the sampling sites were within the recommended guideline set by SANS and $\mathrm{WHO}\left(25^{\circ} \mathrm{C}\right)[25,26]$. The temperature is suitable for use of irrigation (6.5-8.4) and aquaculture (6.5-9), respectively. The $\mathrm{pH}$ of the samples was in the range of 7.03-7.15 (Table 3) and complied with the recommended guidelines for human consumption $[25,26]$. Sudden changes in $\mathrm{pH}$ can have an adverse impact on aquatic biota.

Table 3. Mean concentrations and standard deviation of the physiochemical water quality parameters.

\begin{tabular}{|c|c|c|c|c|c|c|c|c|}
\hline \multirow{2}{*}{ Parameters } & \multirow{2}{*}{$\begin{array}{c}\text { Upstream } \\
\text { Average and SD }\end{array}$} & \multirow{2}{*}{$\begin{array}{c}\text { Midstream } \\
\text { Average and SD }\end{array}$} & \multirow{2}{*}{$\begin{array}{c}\text { Downstream } \\
\text { Average and SD }\end{array}$} & \multirow{2}{*}{ WHO [25] } & \multirow{2}{*}{ SANS [26] } & \multicolumn{3}{|c|}{ Limit of Agriculture Water Use [28] } \\
\hline & & & & & & Livestock & Irrigation & Aquaculture \\
\hline Temperature $\left({ }^{\circ} \mathrm{C}\right)$ & $18.18 \pm 2.43$ & $18.69 \pm 1.44$ & $18.08 \pm 2.29$ & $<25$ & $<25$ & & & \\
\hline $\mathrm{pH}$ & $7.03 \pm 0.13$ & $7.15 \pm 0.4$ & $7.08 \pm 0.19$ & $6.5-8.5$ & $6.5-9.5$ & $\mathrm{n} / \mathrm{a}$ & $6.5-8.4$ & $6.5-9.0$ \\
\hline Salinity (mg/L) & $83.89 \pm 25.15$ & $110.67 \pm 6.69$ & $133.52 \pm 45.04$ & $600-900$ & $<1500$ & $\mathrm{n} / \mathrm{a}$ & $\mathrm{n} / \mathrm{a}$ & $\mathrm{n} / \mathrm{a}$ \\
\hline $\operatorname{TDS}(\mathrm{mg} / \mathrm{L})$ & $126.37 \pm 38.61$ & $166.01 \pm 7.07$ & $167.5 \pm 19.56$ & $0-400$ & $\leq 1200$ & $0-3000$ & $\mathrm{n} / \mathrm{a}$ & $\mathrm{n} / \mathrm{a}$ \\
\hline $\mathrm{EC}(\mu \mathrm{s} / \mathrm{cm})$ & $182.25 \pm 51.65$ & $235.83 \pm 12.97$ & $233.17 \pm 2.51$ & 600.01 & $\leq 1700$ & $\mathrm{n} / \mathrm{a}$ & $0-3000$ & $\mathrm{n} / \mathrm{a}$ \\
\hline Turbidity (NTU) & $5.54 \pm 0.50$ & $3.87 \pm 2.54$ & $3.965 \pm 1.73$ & $<1$ & $<1$ & $\mathrm{n} / \mathrm{a}$ & $\mathrm{n} / \mathrm{a}$ & 25 \\
\hline
\end{tabular}

TDS, total dissolved solids; EC, electrical conductivity; SD, standard deviation; $\mathrm{n}$ /a, guideline value not available.

Salinity level varied between 83.89 and $133.52 \mathrm{mg} / \mathrm{L}$ (Table 3). Excessive salinity may cause eye irritation in human and chlorosis in plants [29]. Mean values of salinity recorded complied with the standard guidelines $[25,26]$. Turbidity levels recorded were above the permissible limit of 1 and $<5$ NTU prescribed by SANS and WHO, respectively, for domestic water use in all sampling points. Average turbidity level of the study ranged from 3.87 to $5.54 \mathrm{NTU}$ (Table 3). However, it was within the permissible limit of aquaculture water use (25 NTU) [28]. The level of turbidity was quite low compared to others reported in the region [30]. Comparable levels have been reported by Ejoh et al. [31] at Ubongo and Egini Rivers, Udu LGA, Delta State Nigeria (2.3-5.8 NTU).

\subsection{Chemical Parameters}

Major Cations and Anions

Fluoride $\left(\mathrm{F}^{-}\right)$is an essential anion in drinking water. Its occurrence in levels $<0.5 \mathrm{mg} / \mathrm{L}$ has been linked with dental caries in children, while higher levels exceeding $1.5 \mathrm{mg} / \mathrm{L}$ can cause dental and skeletal fluorosis as well as non-fluorosis diseases [32,33]. Low levels of fluoride below $0.5 \mathrm{mg} / \mathrm{L}$ were determined in this study (Figure 2). The other anions $\left(\mathrm{Cl}^{-}\right.$, $\mathrm{NO}_{3}{ }^{-}, \mathrm{PO}_{4}{ }^{3-}$, and $\mathrm{SO}_{4}{ }^{2-}$ ) were within the permissible limit for domestic and agricultural water use. The levels of nitrates and phosphates determined in this study can be linked 
with the practice of agriculture around the river course. Figure 2 shows that higher levels of the various anions were recorded at the downstream sampling sites than upstream, which could be due to increase in anthropogenic activities along the river course.

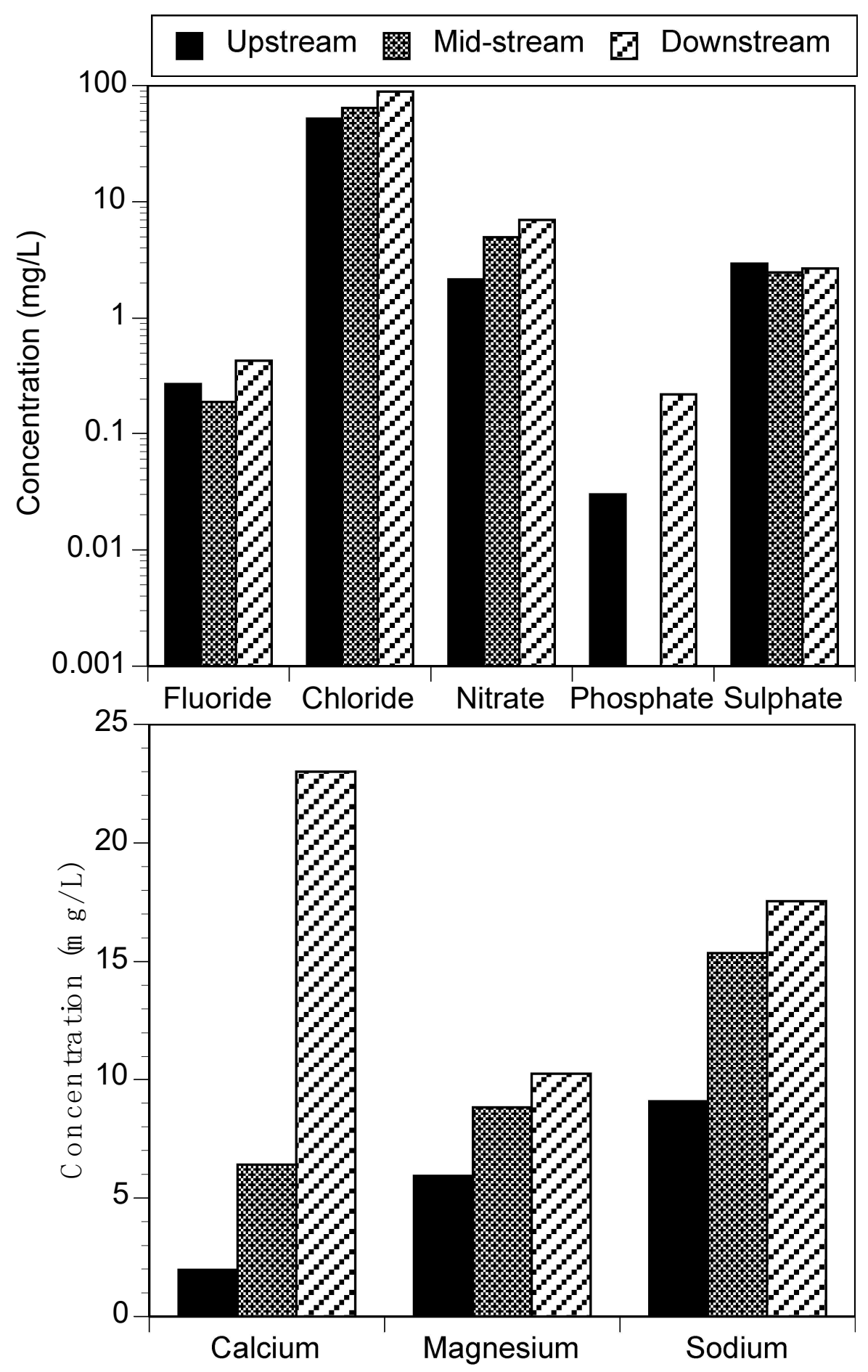

Figure 2. Major anions (top) and cations (bottom) in Mutangwi River.

Concentration of phosphate recorded in all sampling points varied between 0.03 and $0.22 \mathrm{mg} / \mathrm{L}$ (Figure 2) and complied with the regulatory guidelines for domestic purposes, irrigation, and livestock water use. A study by Wei et al. [34]. observed that phosphate in water is not viewed as toxic directly to animals and people. However, its presence in high levels can initiate poisonous algal blooms and hypoxic waters with reduced biotic 
diversity. A study by Awomeso et al. [35] showed that the concentration of phosphates in Nairobi River ranged from 2.0 to $3.34 \mathrm{mg} / \mathrm{L}$.

Sulphate $\left(\mathrm{SO}_{4}^{2-}\right)$ is a crucial and essential nutrient for tissue development in plants and animals. Sulphate levels recorded ranged from 2.46 to $2.94 \mathrm{mg} / \mathrm{L}$ (Figure 2). Concentrations in all sampling points were within the limit of DWAF and WHO for residential water utilization of 200 and $250 \mathrm{mg} / \mathrm{L}$, respectively [25,28]. Nitrogen is important to human health, but a high level in other food products and drinking water could lead to major and serious health problems. The concentration of nitrate varied between 2.15 and $6.98 \mathrm{mg} / \mathrm{L}$ (Figure 2) and complied with the WHO $(50 \mathrm{mg} / \mathrm{L})$ threshold limit for domestic water use [25]. High nitrate $\left(\mathrm{NO}_{3}^{-}\right)$levels in drinking water can cause methemoglobinemia in infants [36,37].

The concentration of chloride ranged from 52.08 to $88.59 \mathrm{mg} / \mathrm{L}$ (Figure 2). Chloride $\left(\mathrm{Cl}^{-}\right)$levels were higher compared with other anions examined in the study but complied with the guideline value for drinking water and agricultural purposes.

Calcium (Ca) is vital major cation for biochemical interactions in living organisms. The recorded levels varied between 1.96 and $23 \mathrm{mg} / \mathrm{L}$ (Figure 2) and complied with regulatory standards for domestic and agricultural water use [28]. Low levels of Sodium (Na) in the range of 9.08-17.55 mg/L (Figure 2) were determined in the study area and complied with several regulatory standards for domestic and agricultural water use. Similarly, low levels of magnesium were also determined in this study. Like the anions, higher levels were found at the downstream sites.

\subsection{Trace Metals Concentration}

The concentration of lead $(\mathrm{Pb})$ ranged from 0.05 to $0.07 \mathrm{mg} / \mathrm{L}$ and exceeded the threshold limit of $0.01 \mathrm{mg} / \mathrm{L}$ for drinking water. The levels found are of health risk to humans and aquatic organisms. High levels of $\mathrm{Pb}$ above $0.01 \mathrm{mg} / \mathrm{L}$ have been linked to anaemia, memory loss, anorexia, brain damage, and death. Furthermore, this finding can be compared to studies reported by Ayandiran et al. [38] in Rupsha and Oluwa Rivers in South West Nigeria.

The levels of cadmium (Cd) determined in this study ranged between 0.01 and $0.02 \mathrm{mg} / \mathrm{L}$ and did not comply with safe levels as stipulated by WHO [25] and SANS [26] (Figure 3). The levels found could cause potential ecological risk of metals to aquatic organisms. Moreover, with respect to $\mathrm{Cd}$, the water is not fit for aquaculture and irrigation of fresh vegetables. The presence of cadmium is a major concern since it can cause potential health risk to humans and aquatic organisms. The levels of cadmium recorded could be from emission through air and water from hazardous waste sites and factories. High levels of $\mathrm{Cd}$ have been linked to several diseases in man and aquatic organisms, including memory loss, reproductive defect, and cancer, as well as damage to the lungs, kidney, and immune system, which could eventually lead to death [39].

Iron is a metal at the dynamic site of numerous significant redox proteins in plants and animals [40]. The concentration of iron ( $\mathrm{Fe}$ ) ranged between 0.18 and $0.3 \mathrm{mg} / \mathrm{L}$ (Figure 3). The SANS guideline of $2 \mathrm{mg} / \mathrm{L}$ associated with chronic effect associated with Fe consumption via water was not exceeded in any of the sampling months. In addition, the aesthetic guideline value of $0.3 \mathrm{mg} / \mathrm{L}$ was not exceeded [25]. High levels of Fe have been associated with several anthropogenic activities such as washing of clothes and cars in rivers. Fe is known to affect the aesthetic property of water, interfering with the taste and appearance of water. The consumption of Fe-rich water has been implicated with negative effects on human health, such as hypertension, congestion of blood vessels, and increased respiration rate [41]. The levels of Mn ranged between 0.01 and $0.05 \mathrm{mg} / \mathrm{L}$ and complied with regulatory standards for drinking and irrigation of fresh vegetables. Both Fe and $\mathrm{Mn}$ can adversely affect the taste of water and influence the water aesthetic properties if their level exceeds the permissible limit [26]. 


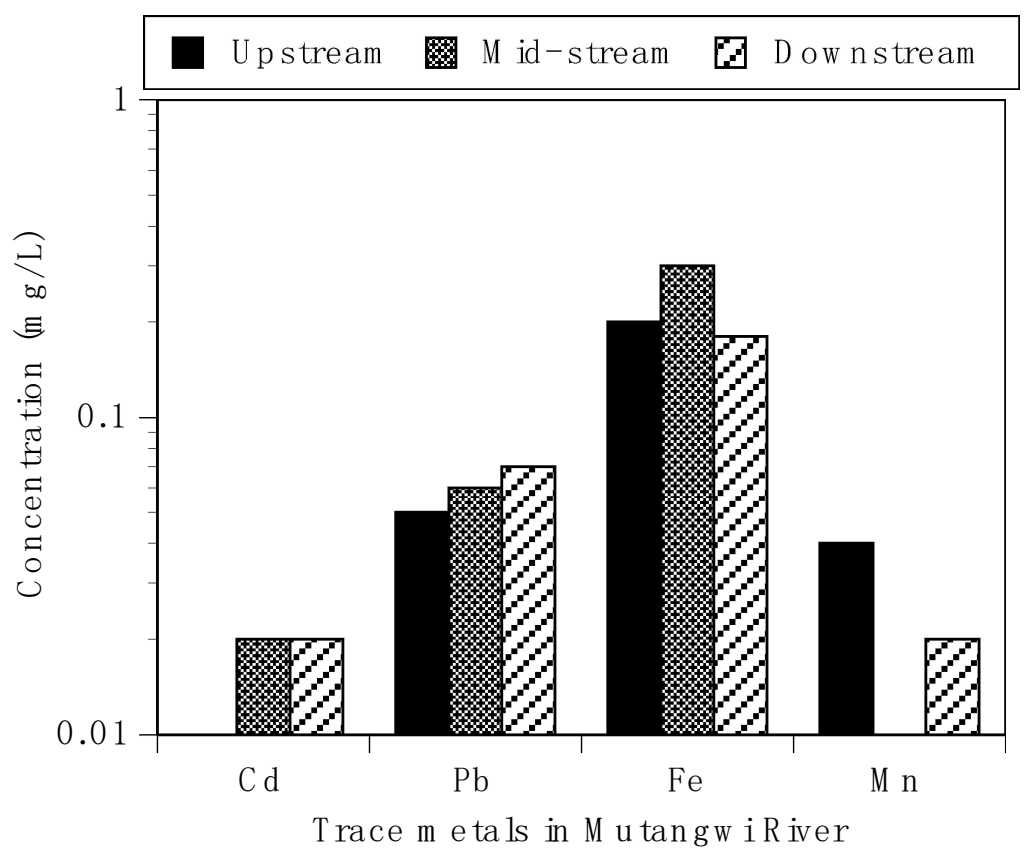

Figure 3. Trace metal concentration in Mutangwi River.

\subsection{Microbiological Parameters}

The values of $E$. coli count were in a range of $814.5-2169 \mathrm{cfu} / 100 \mathrm{~mL}$, and higher values were recorded at the downstream sampling sites of the river (Figure 4 ). This level exceeded the regulatory standards for drinking water $(0 \mathrm{cfu} / 100 \mathrm{~mL})[25,26]$ and agriculture use (irrigation) (1 cfu/100 mL) [28]. Mutangwi River is contaminated with $E$. coli and therefore is not suitable for irrigation, recreation, and domestic purposes without proper treatment. Enterococci levels differed distinctively in each of the sampling points. Enterococci is an opportunist pathogen whose occurrence in freshwater systems has been strongly linked to sewage discharge, and they usually show resistance to antibiotics [42]. They are often considered as a good indicator for the assessment of microbiological risks to humans and aquatic life [43]. Enterococci levels recorded in the study ranged from 333 to $9396 \mathrm{cfu} / 100 \mathrm{~mL}$ and did not comply with regulatory standards (Figure 4).

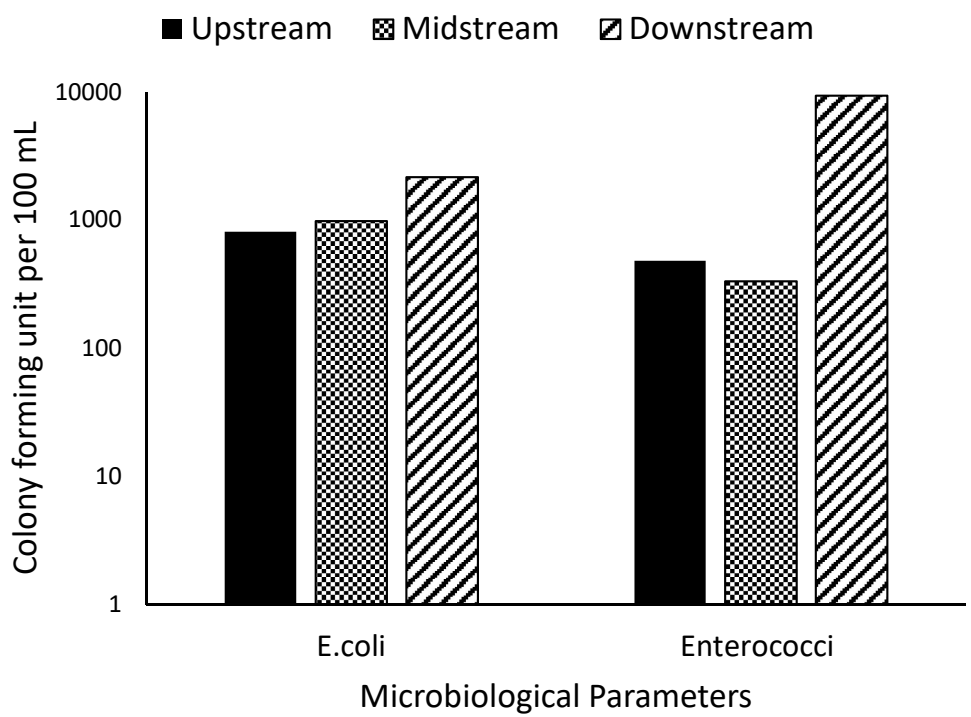

Figure 4. E. coli and Enterococci levels in the sampling sites. 
In various river systems in South Africa, different levels of microbial contamination have been recorded, which often necessitate the need for disinfection before use. Table 4 shows the levels of E. coli and Enterococci reported in some rivers in South Africa. The potential sources of pollution have been linked to surface runoffs, discharge of sewage water, open defecation by free-ranging animals, dumping of diapers by the river bank, etc. $[4,44]$. The consumption of faecal-contaminated water has been implicated in various disease outbreaks, such as diarrhoea and cholera. The consumption of raw vegetables irrigated with faecal-contaminated water in local areas has led to stomach cramps, vomiting, and diarrhoea [45].

Table 4. Comparison levels of E. coli and Enterococci in Mutangwi River and other rivers in South Africa.

\begin{tabular}{llllll}
\hline \multicolumn{1}{c}{ Rivers } & $\begin{array}{l}\text { E. coli } \\
\text { (cfu/100 } \mathbf{~ m L )}\end{array}$ & $\begin{array}{l}\text { Enterococci } \\
(\mathbf{c f u} / \mathbf{1 0 0} \mathbf{~ m L})\end{array}$ & Provinces & Year & References \\
\hline Olifants River & $34-1599$ & $1620-2760$ & Mpumalanga & 2012 & {$[46]$} \\
Tyume River & $100-16,000$ & $33-5100$ & Eastern Cape & 2013 & {$[47]$} \\
Msunduzi River & $1-39$ & $1-79$ & Limpopo & 2013 & {$[48]$} \\
Buffalo River & $0-190$ & $0-5,300,000$ & KwaZulu Natal & 2013 & {$[49]$} \\
Klip and Vaal Rivers & $>5$ & $>40$ & Gauteng & 2014 & {$[50]$} \\
Eerste Rivers & $5-100$ & $17-510$ & Western Cape & 2015 & {$[51]$} \\
Mooi River & $61-548$ & $74-870$ & North West & 2016 & {$[52]$} \\
Mvudi River & $1650-4767$ & $950-11,533$ & Limpopo & 2016 & {$[40]$} \\
Apies River & 3.9 & 3.97 & Gauteng & 2017 & {$[53]$} \\
Luvuvhu River & $>300->400$ & $19,100-25,000$ & Limpopo & 2017 & {$[45]$} \\
Mooder River & $01-62$ & $12-104$ & Free state & 2018 & {$[54]$} \\
Nzhelele River & $100-57,000$ & $100-80,000$ & Limpopo & 2018 & {$[6]$} \\
Mutoti River & $29.2-57.1$ & $20-2180$ & Limpopo & 2020 & {$[55]$} \\
Umhlangane River & 246 & 377 & KwaZulu Natal & 2021 \\
Mutangwi River & $814.5-2169$ & $333-9396$ & Limpopo & 2021 & Current study \\
\hline
\end{tabular}

\subsection{Water Quality Index}

Water Quality Index (WQI) is significant rating that determines the general overall water quality status in a singular term that is useful for the determination of suitable treatment and use $[8,21,57]$. One of the limitations of WQI is that it does not account for microbial water quality parameters.

The WHO guideline for drinking water quality was used for the calculation of WQI. The rating of the river water was computed using the physicochemical parameters obtained. Table 5 shows how the WQI was determined.

Results from Table 5 show that the upstream of Mutangwi River has water of good quality that can be used for various purposes. However, the water quality of the midstream and downstream of the river is poor, and the overall rating of the water quality of the river is poor. Hence, the river water quality is poor both microbiologically and physicochemically and should not be used without appropriate treatment.

There was a strong correlation between nitrate and phosphate with a value of $r=0.74$ (Table 6), inferring that they could be from similar sources such as sewage effluent, drainage from farmland, and fertilizers. A strong correlation exists between TDS and EC $(r=0.99)$, as expected, as they are both directly proportional to each other. The more solids that are dissolved in the water, the higher is the value of the electric conductivity. The sources of ions could be natural, i.e., geological condition, and from human activities such as domestic and industrial waste and also from agricultural activities. E. coli had a strong correlation with Enterococci with $(r=0.99)$ (Table 6). Hence, the presence of E. coli can be used to infer the presence of Enterococci. $\mathrm{Pb}$ showed a strong correlation to $\mathrm{Cd}(r=0.86)$. Other correlation results can be seen in Table 6 . 
Table 5. Physio-chemical parameters used for WQI determination.

\begin{tabular}{|c|c|c|c|c|c|c|c|c|c|c|}
\hline Parameters & Desirable Limit (Si) & $\begin{array}{l}\text { Weight of Each } \\
\text { Parameter }(w i)\end{array}$ & Relative Weight (Wi) & $q i$ upstream & $q i$ Midstream & $q i$ Downstream & WQI Upstream & WQI Midstream & WQI Downstream & WQI (Mean) \\
\hline $\mathrm{pH}$ & $6.5-8.5$ & 4 & 0.0714 & 93.73 & 95.33 & 94.40 & 6.64 & 6.68 & 6.74 & 6.69 \\
\hline TDS (mg/L) & 500 & 4 & 0.0714 & 25.27 & 33.20 & 33.5 & 1.83 & 2.37 & 2.34 & 2.18 \\
\hline $\mathrm{EC}(\mu \mathrm{s} / \mathrm{cm})$ & 600.01 & 4 & 0.0714 & 30.37 & 39.30 & 38.86 & 2.81 & 3.8 & 2.77 & 3.12 \\
\hline Salinity & 600 & 3 & 0.0535 & 13.98 & 18.4 & 22.2 & 0.075 & 0.984 & 1.19 & 0.74 \\
\hline Temperature & 25 & 2 & 0.0357 & 72.72 & 74.76 & 72.32 & 2.59 & 2.66 & 2.5 & 2.58 \\
\hline Fluoride (mg/L) & 1.0 & 4 & 0.0714 & 27.0 & 19.0 & 43.0 & 1.92 & 1.35 & 3.0 & 2.09 \\
\hline Chloride (mg/L) & $\begin{array}{l}1.0 \\
250\end{array}$ & 3 & $\begin{array}{l}0.0535 \\
0.0535\end{array}$ & 20.83 & $\begin{array}{l}19.0 \\
25.72\end{array}$ & 35.44 & 1.11 & $\begin{array}{l}1.30 \\
1.38\end{array}$ & 21.89 & 8.13 \\
\hline Nitrate (mg/L) & 45 & 5 & 0.0892 & 4.77 & 10.97 & 15.51 & 0.42 & 0.97 & 1.38 & 0.92 \\
\hline Sulphate (mg/L) & 200 & 3 & 0.0535 & 1.47 & 1.23 & 1.34 & 0.15 & 0.126 & 0.14 & 0.14 \\
\hline $\mathrm{Fe}(\mathrm{mg} / \mathrm{L})$ & 0.3 & 3 & 0.0535 & 66.66 & 99.9 & 60 & 3.56 & 5.3 & 3.21 & 4.02 \\
\hline $\mathrm{Ca}(\mathrm{mg} / \mathrm{L})$ & 75 & 2 & 0.0357 & 2.68 & 8.5 & 10.27 & 0.09 & 0.30 & 0.36 & 0.25 \\
\hline $\mathrm{Mg}(\mathrm{mg} / \mathrm{L})$ & 30 & 2 & 0.0357 & 19.77 & 29.4 & 34.13 & 0.71 & 1.04 & 1.21 & 0.99 \\
\hline $\mathrm{Na}(\mathrm{mg} / \mathrm{L})$ & 100 & 3 & 0.0535 & 9.08 & 15.32 & 17.55 & 0.48 & 0.81 & 0.93 & 0.74 \\
\hline $\mathrm{Pb}(\mathrm{mg} / \mathrm{L})$ & 0.01 & 5 & 0.0892 & 500 & 600 & 700 & 44.6 & 53.52 & 62.44 & 53.52 \\
\hline \multirow[t]{2}{*}{$\mathrm{Cd}(\mathrm{mg} / \mathrm{L})$} & 0.005 & 5 & 0.0892 & 200 & 400 & 400 & 17.84 & 35.68 & 35.68 & 29.73 \\
\hline & & $\sum w i=56$ & $\sum w i=1.00$ & & & & $\sum \mathrm{WQI}=84.82$ & $\sum \mathrm{WQI}=116.97$ & $\sum \mathrm{WQI}=145.78$ & 115.86 \\
\hline
\end{tabular}

Table 6. Statistical analysis of correlation result.

\begin{tabular}{|c|c|c|c|c|c|c|c|c|c|c|c|c|c|c|c|c|c|c|c|c|}
\hline Parameters & Temp. $\left({ }^{\circ} \mathrm{C}\right)$ & $\mathrm{pH}$ & Salinity & TDS & EC & Turb. & $F^{-}$ & $\mathrm{Cl}^{-}$ & $\mathrm{NO}_{3}^{-}$ & $\mathrm{PO}_{4}{ }^{3-}$ & $\mathrm{SO}_{4}{ }^{2-}$ & E. coli & Enterococci & $\mathrm{Fe}$ & Mn & $\mathbf{P b}$ & $\mathrm{Ca}$ & $\mathrm{Mg}$ & $\mathrm{Na}$ & $\mathrm{Cd}$ \\
\hline Temp. $\left({ }^{\circ} \mathrm{C}\right)$ & 1 & 1 & & & & & & & & & & & & & & & & & & \\
\hline Salinity (mg/L) & -0.11 & 0.45 & 1 & & & & & & & & & & & & & & & & & \\
\hline TDS $(\mathrm{mg} / \mathrm{L})$ & 0.33 & 0.79 & 0.9 & 1 & & & & & & & & & & & & & & & & \\
\hline $\begin{array}{l}\text { EC ( }(\text { s } / \mathrm{cm}) \\
\text { Turb. (NTU) }\end{array}$ & $\begin{array}{c}0.4 \\
-0.41\end{array}$ & $\begin{array}{c}0.83 \\
-0.84\end{array}$ & $\begin{array}{c}0.86 \\
-0.86\end{array}$ & $\begin{array}{c}0.99 \\
-0.99\end{array}$ & $\begin{array}{c}1 \\
-0.99\end{array}$ & 1 & & & & & & & & & & & & & & \\
\hline $\begin{array}{l}\text { Turb. (NTU) } \\
\mathrm{F}^{-} \text {(mg/L) }\end{array}$ & -0.85 & -0.41 & & & 0.14 & $\begin{array}{c}1 \\
-0.139\end{array}$ & 1 & & & & & & & & & & & & & \\
\hline $\begin{array}{l}\mathrm{F}^{-}(\mathrm{mg} / \mathrm{L}) \\
\mathrm{Cl}^{-}(\mathrm{mg} / \mathrm{L})\end{array}$ & -0.36 & 0.23 & $\begin{array}{l}0.61 \\
0.97\end{array}$ & $\begin{array}{l}0.22 \\
0.77\end{array}$ & & & $\begin{array}{c}1 \\
0.78\end{array}$ & & & & & & & & & & & & & \\
\hline $\mathrm{Cl}^{-}(\mathrm{mg} / \mathrm{L})$ & -0.36 & 0.23 & 0.97 & 0.77 & 0.72 & $\begin{array}{l}-0.72 \\
-0.88\end{array}$ & 0.78 & 1 & & & & & & & & & & & & \\
\hline $\mathrm{NO}_{3}(\mathrm{mg} / \mathrm{L})$ & -0.06 & 0.49 & 0.99 & 0.92 & 0.88 & -0.88 & 0.58 & 0.96 & 1 & & & & & & & & & & & \\
\hline $\begin{array}{l}\mathrm{PO}_{4}^{3-}(\mathrm{mg} / \mathrm{L}) \\
\mathrm{SO}_{4}^{2-}(\mathrm{mg} / \mathrm{L})\end{array}$ & $\begin{array}{l}-0.72 \\
-0.73\end{array}$ & $\begin{array}{l}-0.21 \\
-0.98\end{array}$ & $\begin{array}{c}0.77 \\
-0.59\end{array}$ & $\begin{array}{c}0.41 \\
-0.88\end{array}$ & $\begin{array}{c}0.34 \\
-0.91\end{array}$ & $\begin{array}{c}-0.34 \\
0.92\end{array}$ & $\begin{array}{l}0.97 \\
0.25\end{array}$ & $\begin{array}{c}0.89 \\
-0.39\end{array}$ & $\begin{array}{c}0.74 \\
-0.63\end{array}$ & $\begin{array}{c}1 \\
0.05\end{array}$ & 1 & & & & & & & & & \\
\hline $\begin{array}{l}\text { E. coli } \\
\text { (cfu } / 100 \mathrm{~mL})\end{array}$ & -0.53 & 0.01 & 0.89 & 0.62 & 0.55 & -0.55 & 0.9 & 0.97 & 0.87 & 0.97 & -0.18 & 1 & & & & & & & & \\
\hline $\begin{array}{l}\text { Enterococci } \\
\text { (cfu/100mL) }\end{array}$ & -0.64 & -0.1 & 0.83 & 0.51 & 0.44 & -0.44 & 0.94 & 0.93 & 0.8 & 0.99 & -0.05 & 0.99 & 1 & & & & & & & \\
\hline $\begin{array}{l}\mathrm{Fe}(\mathrm{mg} / \mathrm{L}) \\
\mathrm{Mn}(\mathrm{mg} / \mathrm{L})\end{array}$ & $\begin{array}{c}0.99 \\
-0.64\end{array}$ & $\begin{array}{c}0.83 \\
-0.95\end{array}$ & $\begin{array}{l}-0.11 \\
-0.68\end{array}$ & $\begin{array}{c}0.3 \\
-0.93\end{array}$ & 0.39 & -0.4 & -0.84 & -0.33 & -0.06 & -0.71 & -0.73 & -0.53 & -0.63 & 1 & & & & & & \\
\hline $\begin{array}{l}\mathrm{Mn}(\mathrm{mg} / \mathrm{L}) \\
\mathrm{Pb}(\mathrm{mg} / \mathrm{L})\end{array}$ & $\begin{array}{l}-0.64 \\
-0.15\end{array}$ & $\begin{array}{l}-0.95 \\
0.41\end{array}$ & $\begin{array}{c}-0.68 \\
0.99\end{array}$ & $\begin{array}{l}-0.93 \\
0.88\end{array}$ & $\begin{array}{l}-0.95 \\
0.84\end{array}$ & $\begin{array}{c}0.96 \\
-0.83\end{array}$ & $\begin{array}{l}0.14 \\
0.65\end{array}$ & $\begin{array}{l}-0.5 \\
0.98\end{array}$ & $\begin{array}{c}-0.71 \\
0.99\end{array}$ & $\begin{array}{l}-0.06 \\
0.79\end{array}$ & $\begin{array}{c}0.99 \\
-0.56\end{array}$ & $\begin{array}{l}-0.29 \\
0.91\end{array}$ & $\begin{array}{l}-0.17 \\
0.85\end{array}$ & -0.6 & 1 & 1 & & & & \\
\hline $\begin{array}{l}\mathrm{Pb}(\mathrm{mg} / \mathrm{L}) \\
\mathrm{Ca}(\mathrm{mg} / \mathrm{L})\end{array}$ & $\begin{array}{l}-0.15 \\
0.15\end{array}$ & $\begin{array}{l}0.41 \\
0.66\end{array}$ & 0.96 & 0.98 & $\begin{array}{l}0.04 \\
0.96\end{array}$ & $\begin{array}{l}-0.03 \\
-0.96\end{array}$ & 0.39 & $\begin{array}{l}.90 \\
0.88\end{array}$ & $\begin{array}{l}0.99 \\
0.97\end{array}$ & 0.58 & $\begin{array}{l}-0.56 \\
-0.78\end{array}$ & 0.75 & $\begin{array}{l}0.85 \\
0.66\end{array}$ & $\begin{array}{l}-0.2 \\
0.14\end{array}$ & $\begin{array}{l}-0.7 \\
-0.9\end{array}$ & $\begin{array}{c}1 \\
0.95\end{array}$ & 1 & & & \\
\hline $\mathrm{Mg}(\mathrm{mg} / \mathrm{L})$ & 0.04 & 0.58 & 0.98 & 0.95 & 0.93 & -0.92 & 0.49 & 0.92 & 0.99 & 0.66 & -0.71 & 0.82 & 0.74 & 0.03 & -0.8 & 0.98 & 0.99 & 1 & & \\
\hline $\mathrm{Na}(\mathrm{mg} / \mathrm{L})$ & 0.12 & 0.64 & 0.97 & 0.97 & 0.95 & -0.95 & 0.42 & 0.89 & 0.98 & 0.6 & -0.76 & 0.77 & 0.68 & 0.12 & -0.8 & 0.96 & 0.99 & 0.99 & 1 & \\
\hline $\mathrm{Cd}(\mathrm{mg} / \mathrm{L})$ & 0.36 & 0.81 & 0.88 & 0.99 & 0.99 & -0.99 & 0.18 & 0.75 & 0.9 & 0.39 & -0.89 & 0.59 & 0.48 & 0.35 & -0.9 & 0.86 & 0.97 & 0.94 & 0.96 & 1 \\
\hline
\end{tabular}

Temp., temperature; Turb., turbidity; $\mathrm{F}^{-}$, fluoride; $\mathrm{Cl}^{-}$, chloride; $\mathrm{NO}_{3}{ }^{-}$, nitrate; $\mathrm{PO}_{4}{ }^{3-}$, phosphate; $\mathrm{SO}_{4}{ }^{2-}$, sulphate. 


\subsection{Human Health Risk Assessment}

\subsubsection{Noncarcinogenic risk}

Summary of Hazard Quotient $(\mathrm{HQ})$ values for some trace elements $(\mathrm{Pb}, \mathrm{Cd}, \mathrm{Mn}$, and $\mathrm{Fe}$ ) in drinking water through ingestion and dermal routes were computed for adults and children (Tables 7 and 8). The trace metals can pose potential adverse health effects when the HQ value of a metal is higher than 1 [58]. The HQ through ingestion and dermal exposure for both children and adult groups did not exceed 1 in all sampling points as well as the hazard index (HI). Hence, we did not find evidence for noncarcinogenic risk related to trace elements $(\mathrm{Pb}, \mathrm{Cd}, \mathrm{Mn}$, and $\mathrm{Fe})$ in Mutangwi River. The occurrence of acute illness, however, is expected due to the levels of E. coli and enterococci recorded. Similar findings have been reported in previous studies [59-62].

Table 7. Human health risk assessment indices for cancer risks from ingestion and absorption of studied metals for the adults.

\begin{tabular}{llcccc}
\hline Parameters & Sampling Points & $\boldsymbol{E X P}_{\text {ing }}$ & $\boldsymbol{E X P}_{\text {der }}$ & $\boldsymbol{H Q}_{\text {ing }}$ & $\boldsymbol{C R}_{\text {ing }}$ \\
\hline \multirow{3}{*}{$\mathrm{Cd}$} & Upstream & $3.14 \times 10^{-4}$ & $1.49 \times 10^{-6}$ & $6.29 \times 10^{-4}$ & $5.15 \times 10^{-5}$ \\
& Midstream & $6.29 \times 10^{-4}$ & $2.98 \times 10^{-6}$ & $1.26 \times 10^{-3}$ & $1.03 \times 10^{-4}$ \\
& Downstream & $6.29 \times 10^{-4}$ & $2.98 \times 10^{-6}$ & $1.26 \times 10^{-3}$ & $1.03 \times 10^{-4}$ \\
\hline \multirow{3}{*}{$\mathrm{Pb}$} & Upstream & $1.57 \times 10^{-4}$ & $2.98 \times 10^{-5}$ & $1.12 \times 10^{-3}$ & $1.75 \times 10^{-1}$ \\
& Midstream & $1.89 \times 10^{-4}$ & $3.58 \times 10^{-5}$ & $1.35 \times 10^{-3}$ & $2.10 \times 10^{-1}$ \\
& Downstream & $2.20 \times 10^{-4}$ & $4.18 \times 10^{-5}$ & $1.57 \times 10^{-3}$ & $2.44 \times 10^{-1}$ \\
\hline \multirow{3}{*}{$\mathrm{Mn}$} & Upstream & $1.26 \times 10^{-3}$ & $5.97 \times 10^{-6}$ & $5.24 \times 10^{-5}$ & - \\
& Midstream & $3.14 \times 10^{-4}$ & $1.49 \times 10^{-6}$ & $1.31 \times 10^{-5}$ & - \\
\hline \multirow{3}{*}{$\mathrm{Fe}$} & Downstream & $6.29 \times 10^{-4}$ & $2.98 \times 10^{-6}$ & $2.62 \times 10^{-5}$ & - \\
& Upstream & $6.29 \times 10^{-3}$ & $2.98 \times 10^{-5}$ & $8.98 \times 10^{-6}$ & - \\
\hline \multirow{3}{*}{$\mathrm{HI}$} & Midstream & $9.43 \times 10^{-4}$ & $4.47 \times 10^{-5}$ & $1.35 \times 10^{-5}$ & - \\
& Downstream & $5.66 \times 10^{-3}$ & $2.68 \times 10^{-5}$ & $8.08 \times 10^{-6}$ & - \\
\hline
\end{tabular}

HI, hazard index; -, not applicable.

Table 8. Human health risk assessment indices for cancer risks from ingestion and absorption of studied metals for the children.

\begin{tabular}{|c|c|c|c|c|c|}
\hline Parameters & Sampling Points & $E X P_{\text {ing }}$ & $E X P_{d e r}$ & $H Q_{i n g}$ & $C R_{\text {ing }}$ \\
\hline \multirow{3}{*}{$\mathrm{Cd}$} & Upstream & $6.92 \times 10^{-3}$ & $6.92 \times 10^{-3}$ & $6.92 \times 10^{-3}$ & $6.67 \times 10^{-1}$ \\
\hline & Midstream & $1.00 \times 10^{-2}$ & $1.00 \times 10^{-2}$ & $1.00 \times 10^{-2}$ & $1.31 \times 10^{-1}$ \\
\hline & Downstream & $1.09 \times 10^{-2}$ & $1.09 \times 10^{-2}$ & $1.09 \times 10^{-2}$ & $9.33 \times 10^{-1}$ \\
\hline \multirow{3}{*}{$\mathrm{Pb}$} & Upstream & $6.92 \times 10^{-3}$ & $6.92 \times 10^{-3}$ & $6.92 \times 10^{-3}$ & $6.67 \times 10^{-1}$ \\
\hline & Midstream & $1.00 \times 10^{-2}$ & $1.00 \times 10^{-2}$ & $1.00 \times 10^{-2}$ & $1.31 \times 10^{-1}$ \\
\hline & Downstream & $1.09 \times 10^{-2}$ & $1.09 \times 10^{-2}$ & $1.09 \times 10^{-2}$ & $9.33 \times 10^{-1}$ \\
\hline \multirow{3}{*}{$\mathrm{Mn}$} & Upstream & $6.92 \times 10^{-3}$ & $6.92 \times 10^{-3}$ & $6.92 \times 10^{-3}$ & - \\
\hline & Midstream & $1.00 \times 10^{-2}$ & $1.00 \times 10^{-2}$ & $1.00 \times 10^{-2}$ & - \\
\hline & Downstream & $1.09 \times 10^{-2}$ & $1.09 \times 10^{-2}$ & $1.09 \times 10^{-2}$ & - \\
\hline \multirow{3}{*}{$\mathrm{Fe}$} & Upstream & $6.92 \times 10^{-3}$ & $6.92 \times 10^{-3}$ & $6.92 \times 10^{-3}$ & - \\
\hline & Midstream & $1.00 \times 10^{-2}$ & $1.00 \times 10^{-2}$ & $1.00 \times 10^{-2}$ & - \\
\hline & Downstream & $1.09 \times 10^{-2}$ & $1.09 \times 10^{-2}$ & $1.09 \times 10^{-2}$ & - \\
\hline \multirow{3}{*}{$\mathrm{HI}$} & Upstream & - & - & $6.92 \times 10^{-3}$ & - \\
\hline & Midstream & - & - & $1.00 \times 10^{-2}$ & - \\
\hline & Downstream & - & - & $1.09 \times 10^{-2}$ & - \\
\hline
\end{tabular}




\subsubsection{Carcinogenic Risk (CR)}

The cancer risk was computed based on the intake level of inorganic $\mathrm{Pb}$ and $\mathrm{Cd}$, which may increase carcinogenic effects depending on the exposure dose and duration of exposure. Only metals that are carcinogenic in nature were used in this computation. Considering ingestion exposure pathways, estimated $C R_{\text {ingestion }}$ values for adults were in the range of $\left(5.15 \times 10^{-5}\right.$ to $\left.1.75 \times 10^{-1}\right)$ and were $\left(1.31 \times 10^{-1}\right.$ to $\left.9.33 \times 10^{-1}\right)$ for children. The average values of $C R_{\text {ing }}$ for adults and children were $1.80 \times 10^{-1}$ and $9.89 \times 10^{-1}$, respectively. $\mathrm{Pb}$ had the highest average contribution of $\mathrm{CR}$ compared to $\mathrm{Cd}$. $C R_{\text {ing }}$ levels of $\mathrm{Pb}$ exceeded the threshold for both children and adults for all selected sampling points (Tables 7 and 8). This result clearly shows that children are more vulnerable to health risks associated with drinking water than adults. Similar studies showing the vulnerability of children to chemical contaminants in food and water have been reported [63,64]. These findings imply that the water is of a poor quality and should be treated prior to domestic water use. The use of water with $\mathrm{Pb}$ and $\mathrm{Cd}$ levels higher than the permissible limit can also be of health risk to the fishes that live in the water.

\section{Conclusions}

The results obtained in this study have presented baseline data on the water quality of Mutangwi River. All the physicochemical parameters, except for turbidity, complied with regulatory standards, as did the levels of the anions. All the major cations also fell within the standard limit. $\mathrm{Pb}$ and $\mathrm{Cd}$ were present in elevated levels above the threshold limit of SANS and WHO. Similarly, the levels of faecal coliform bacteria recorded did not comply with regulatory standards. The downstream of the river was more contaminated compared to the upstream and midstream. The WQI showed that the quality of the upstream of the river can be regarded as good while the mid and downstream are poor and need treatment before use. Due to the levels of microbes in the water, the water quality of Mutangwi River can be regarded as poor, although it can be used for irrigation of tree crops. There was no potential noncarcinogenic risk $(\mathrm{HQ}<1)$ associated with the consumption of the river water. However, carcinogenic risk was computed for both children and adults. Therefore, adequate treatment of water from this river is highly recommended.

Author Contributions: Conceptualization, R.T.M., J.N.E. and E.T.V.; sampling and data analysis, R.T.M., J.N.E. and O.S.D.; manuscript-original draft preparation, R.T.M., J.N.E., O.S.D. and J.O.O.; writing-review and editing, R.T.M., J.N.E., O.S.D., E.T.V. and J.O.O.; funding acquisition, J.N.E. All authors have read and agreed to the published version of the manuscript.

Funding: This research was partly supported with the National Research Foundation grant offered to J.N.E. (UID:127276).

Institutional Review Board Statement: Not applicable.

Informed Consent Statement: Not applicable.

Data Availability Statement: The data that support the findings of this study are available from the corresponding author, upon reasonable request.

Acknowledgments: The authors would love to extend their acknowledgements all the professionals who contributed to the collection of the data, the teamwork, commitment, and passion to make this possible.

Conflicts of Interest: The authors declare no conflict of interest.

\section{References}

1. Edokpayi, J.N.; Makungo, R.; Mathivha, F.; Rivers, N.; Volenzo, T.; Odiyo, J.O. Influence of global climate change on water resources in South Africa: Toward an adaptive management approach. In Water Conservation and Wastewater Treatment in BRICS Nations; Singh, P., Milshina, Y., Tian, K., Gusain, D., Bassin, J., Eds.; Elsevier: Amsterdam, The Netherlands, 2020; Chapter 5; pp. 83-115. ISBN 9780128183397. [CrossRef]

2. DWAF. Guideline for the Management of Waterborne Epidemics, with the Emphasis on Cholera, 1st ed.; Water Quality Management Series Guideline Document U1.5; Department of Water Affairs and Forestry: Pretoria, South Africa, 2002. 
3. Centre of Scientific Research. A CSIR Perspective on Water in South Africa; CSIR Report No. CSIR/NRE/PW/IR/2011/0012/A; Centre of Scientific Research: Pretoria, South Africa, 2010.

4. Edokpayi, J.N.; Rogawski, E.T.; Kahler, D.M.; Hill, C.L.; Reynolds, C.; Nyathi, E.; Smith, J.A.; Odiyo, J.O.; Samie, A.; Bessong, P.; et al. Challenges to Sustainable Safe Drinking Water: A Case Study of Water Quality and Use across Seasons in Rural Communities in Limpopo Province, South Africa. Water 2018, 10, 159. [CrossRef]

5. Tortajada, C.; Biswas, A.K. Achieving universal access to clean water and sanitation in an era of water scarcity: Strengthening contributions from academia. Curr. Opin. Environ. Sustain. 2018, 34, 21-25. [CrossRef]

6. Zakir, H.; Sharmin, S.; Akter, A.; Rahman, S. Assessment of health risk of heavy metals and water quality indices for irrigation and drinking suitability of waters: A case study of Jamalpur Sadar area, Bangladesh. Environ. Adv. 2020, 2, 100005. [CrossRef]

7. Janoska, O.; Gruszecka-Kosowska, A. Water quality and Human Health Risk Assessment: A case study of the Czarna Przemsza River source in Zawiercie, Poland. Hum. Ecol. Risk Assess. Int. J. 2018, 26, 757-781. [CrossRef]

8. Olasoji, S.O.; Oyewole, N.O.; Abiola, B.; Edokpayi, J.N. Water Quality Assessment of Surface and Groundwater Sources Using a Water Quality Index Method: A Case Study of a Peri-Urban Town in Southwest, Nigeria. Environments 2019, 6, 23. [CrossRef]

9. Gao, B.; Gao, L.; Gao, J.; Xu, D.; Wang, Q.; Sun, K. Simultaneous evaluations of occurrence and probabilistic human health risk associated with trace elements in typical drinking water sources from major river basins in China. Sci. Total Environ. 2019, 666, 139-146. [CrossRef]

10. Edokpayi, J.N.; Enitan-Folami, A.M.; Adeeyo, A.O.; Durowoju, O.; Jegede, A.O.; Odiyo, J.O. Recent trends and national policies for water provision and wastewater treatment in South Africa. In Water Conservation and Wastewater Treatment in BRICS Nations; Singh, P., Milshina, Y., Tian, K., Gusain, D., Bassin, J., Eds.; Elsevier: Amsterdam, The Netherlands, 2020; Chapter 10; pp. 187-221. ISBN 9780128183397. [CrossRef]

11. Edokpayi, J.N.; Odiyo, J.O.; Popoola, E.O.; Msagati, T.A. Evaluation of microbiological and physicochemical parameters of alternative source of drinking water: A case study of Nzhelele River. South Africa. Open Microbiol. J. 2018, 12, 18. [CrossRef]

12. Edokpayi, J.N.; Odiyo, J.O.; Popoola, O.E.; Msagati, T.A. Evaluation of contaminants removal by waste stabilization ponds: A case study of Siloam WSPs in Vhembe District, South Africa. Heliyon 2021, 7, e06207. [CrossRef] [PubMed]

13. Zhang, Q.; Xu, P.; Qian, H. Assessment of Groundwater Quality and Human Health Risk (HHR) Evaluation of Nitrate in the Central-Western Guanzhong Basin, China. Int. J. Environ. Res. Public Health 2019, 16, 4246. [CrossRef]

14. Wu, J.; Lu, J.; Wen, X.; Zhang, Z.; Lin, Y. Severe Nitrate Pollution and Health Risks of Coastal Aquifer Simultaneously Influenced by Saltwater Intrusion and Intensive Anthropogenic Activities. Arch. Environ. Contam. Toxicol. 2019, 77, 79-87. [CrossRef]

15. Strehmel, A.; Schmalz, B.; Fohrer, N. Evaluation of land use. Land management and soil conservation strategies to reduce non-point source pollution loads in the three gorges region. China. Environ. Manag. 2016, 58, 906-921. [CrossRef] [PubMed]

16. Office of the Mayor, Vhembe District Municipality. Vhembe District Municipality Integrated Development Plan (IDP). 2018-2019; Vhembe District Municipality: Limpopo Province, South Africa, 2018.

17. APHA (American Public Health Association). Standard Methods for the Examination of Water and Wastewater, 18th ed.; American Public Health Association: Washington, DC, USA, 1992; pp. 518-523.

18. Li, S.; Zhang, Q. Spatial characterization of dissolved trace elements and heavy metals in the upper Han River (China) using multivariate statistical techniques. J. Hazard. Mater. 2010, 176, 579-588. [CrossRef] [PubMed]

19. Ramyapriya, R.; Elango, L. Evaluation of geogenic and anthropogenic impacts on spatio-temporal variation in quality of surface water and groundwater along Cauvery River, India. Environ. Earth Sci. 2017, 77, 2. [CrossRef]

20. Singh, S.; Hussian, A. Water quality index development for groundwater quality assessment of Greater Noida sub-basin, Uttar Pradesh, India. Cogent Eng. 2016, 3, 1177155. [CrossRef]

21. USEPA (US Environmental Protection Agency). Risk Assessment Guidance for Superfund. In Human Health Evaluation Manual; USEPA: Washington, DC, USA, 1989; Volume I, EPA/540/1-89/002.

22. Edokpayi, J.N.; Enitan, A.M.; Mutileni, N.; Odiyo, J.O. Evaluation of water quality and human risk assessment due to heavy metals in groundwater around Muledane area of Vhembe District, Limpopo Province, South Africa. Chem. Central J. 2018, 12, 2. [CrossRef] [PubMed]

23. Iqbal, J.; Shah, M.H. Health Risk Assessment of Metals in Surface Water from Freshwater Source Lakes, Pakistan. Hum. Ecol. Risk Assess. Int. J. 2013, 19, 1530-1543. [CrossRef]

24. USEPA. Drinking Water Standards and Health Advisories, EPA 822-R09-011; Office of Water: Washington, DC, USA, 2009.

25. WHO. Guidelines for Drinking-Water Quality, 4th ed.; WHO: Geneva, Switzerland, 2011; p. 155.

26. SANS. South African National Standards 241-1-2015, 2nd ed.; SABS: Pretoria, South Africa, 2015.

27. Lushchak. V.I. Environmentally induced oxidative stress in aquatic animals. Aquat. Toxicol. 2011, 101, 13-30. [CrossRef]

28. Department of Water Affairs and Forestry (DWAF). South African Water Quality Guidelines. Volume 7: Aquatic Ecosystems; Department of Water and Sanitation: Pretoria, South Africa, 1996.

29. Pawari, M.J.; Gawande, S. Assessment of underground water quality around Hadapsar region in Pune, Maharashtra. Int. Res. J. Eng. Technol. 2015, 2, 943-950.

30. Edokpayi, J.N.; Odiyo, J.O.; Popoola, E.O.; Msagati, T. Evaluation of temporary seasonal variation of heavy metals and their potential ecological risk in Nzhelele River, South Africa. Open Chem. 2017, 15, 272-282. [CrossRef]

31. Ejoh, A.; Unuakpa, B.; Ibadin, F.; Edeki, S. Dataset on the assessment of water quality and water quality index of Ubogo and Egini rivers, Udu LGA, Delta State Nigeria. Data Brief. 2018, 19, 1716-1726. [CrossRef] 
32. Onipe, T.; Edokpayi, J.N.; Odiyo, J.O. A review on the potential sources and health implications of fluoride in groundwater of Sub-Saharan Africa. J. Environ. Sci. Health Part A 2020, 55, 1078-1093. [CrossRef] [PubMed]

33. Ayele, B.A.; Yifru, Y.M.; Tekle-Haimanot, R.; Godebo, T.R. Neuro-medical complications of fluoride toxicity among populations living in fluorosis endemic region of the Ethiopian Rift Valley. Res. Sq. 2019. (preprint). [CrossRef]

34. Wei, K.; Yin, H.; Peng, H.; Lu, G.; Dang, Z. Bioremediation of triphenyl phosphate in river water microcosms: Proteome alteration of Brevibacillus brevis and cytotoxicity assessments. Sci. Total Environ. 2019, 649, 563-570. [CrossRef]

35. Awomeso, J.; Taiwo, A.; Idowu, O.; Gbadebo, A.; Oyetunde, O. Assessment of water quality of Ogun River in southwestern Nigeria. IFE J. Sci. 2019, 21, 375. [CrossRef]

36. Nartey, V.K.; Hayford, E.K.; Ametsi, S.K. Assessment of the impact of solid waste dumpsites on some surface water systems in the Accra Metropolitan Area. Ghana. J. Water Resour. Prot. 2012, 4, 605. [CrossRef]

37. Fox, C.; Richardson, K.; Maidment, I.D.; Savva, G.; Matthews, F.; Smithard, D.; Coulton, S.; Katona, C.; Boustani, M.A.; Brayne, C. Anticholinergic Medication Use and Cognitive Impairment in the Older Population: The Medical Research Council Cognitive Function and Ageing Study. J. Am. Geriatr. Soc. 2011, 59, 1477-1483. [CrossRef] [PubMed]

38. Ayandiran, T.; Fawole, O.; Dahunsi, S. Water quality assessment of bitumen polluted Oluwa River, South-Western Nigeria. Water Resour. Ind. 2018, 19, 13-24. [CrossRef]

39. WHO/UNICEF Joint Water Supply and Sanitation Monitoring Programme. In Progress on Sanitation and Drinking Water. Update and MDG Assessment; World Health Organization: Geneva, Switzerland, 2015.

40. Edokpayi, J.N.; Odiyo, J.O.; Popoola, O.; Msagati, T. Assessment of trace metals contamination of surface water and sediment: A case study of Mvudi River. South Africa. Sustainability 2016, 8, 135. [CrossRef]

41. Islam, M.S.; Mohanta, S.C.; Siddique, M.A.B.; Abdullah-Al-Mamun, M.; Hossain, N.; Bithi, U.H. Physico-chemical assessment of water quality parameters in Rupsha river of Khulna region, Bangladesh. Int. J. Eng. Sci. 2018, 7, 73-78.

42. Al-Gheethi, A.A.; Efaq, A.N.; Bala, J.D.; Norli, I.; Abdel-Monem, M.O.; Ab Kadir, M.O. Removal of pathogenic bacteria from sewage-treated effluent and biosolids for agricultural purposes. Appl. Water Sci. 2018, 8, 74. [CrossRef]

43. Liu, Y.; He, Y.; Li, M.; Wang, J.; Liu, K.; Li, X. Does Wireless Sensor Network Scale? A Measurement Study on GreenOrbs. IEEE Trans. Parallel Distrib. Syst. 2013, 24, 1983-1993. [CrossRef]

44. Edokpayi, J.N.; Odiyo, J.A.; Msagati, T.A.; Potgieter, N. Preliminary monitoring of faecal indicator organisms of surface water: A case study of Mvudi River, South Africa. J. Sci. Technol. 2016, 36, 33. [CrossRef]

45. Mailula, M.A.; Gumbo, J.R. Assessment of Microbial Quality of Surface Water Sources of Luvuvhu River Catchment, South Africa. 2017. Available online: http:/ /hdl.handle.net/11602/1278 (accessed on 19 March 2020).

46. Le Roux, W.J.; Schaefer, L.M.; Genthe, B. Microbial water quality in the upper Olifants River catchment; implications for health. Afr. J. Microbiol. Res. 2012, 6, 6580-6588.

47. Sibanda, T.; Chigor, V.N.; Okoh, A.I. Seasonal and spatio-temporal distribution of faecal-indicator bacteria in Tyume River in the Eastern Cape Province, South Africa. Environ. Monit. Assess. 2013, 185, 6579-6590. [CrossRef] [PubMed]

48. Gemmell, M.E.; Schmidt, S. Is the microbiological quality of the Msunduzi River (KwaZulu-Natal, South Africa) suitable for domestic, recreational, and agricultural purposes? Environ. Sci. Pollut. Res. 2013, 20, 6551-6562. [CrossRef]

49. Chigor, V.N.; Sibanda, T.; Okoh, A.I. Studies on the bacteriological qualities of the Buffalo River and three source water dams along its course in the Eastern Cape Province of South Africa. Environ. Sci. Pollut. Res. 2012, 20, 4125-4136. [CrossRef]

50. Teklehaimanot, G.Z.; Coetzee, M.A.A.; Momba, M.N.B. Faecal pollution loads in the wastewater effluents and receiving water bodies: A potential threat to the health of Sedibeng and Soshanguve communities, South Africa. Environ. Sci. Pollut. Res. 2014, 21, 9589-9603. [CrossRef]

51. Britz, T.; Sigge, G.; Huisamen, N.; Kikine, T.; Ackermann, A.; Lötter, M.; Lamprecht, C.; Kidd, M. Fluctuations of indicator and index microbes as indication of pollution over three years in the Plankenburg and Eerste Rivers, Western Cape, South Africa. Water SA 2013, 39, 457-466. [CrossRef]

52. Jordaan, K.; Bezuidenhout, C.C. Bacterial community composition of an urban river in the North West Province, South Africa, in relation to physico-chemical water quality. Environ. Sci. Pollut. Res. 2015, 23, 5868-5880. [CrossRef] [PubMed]

53. Ekwanzala, M.D.; Abia, A.L.K.; Ubomba-Jaswa, E.; Keshri, J.; Momba, N.B.M. Genetic relatedness of faecal coliforms and enterococci bacteria isolated from water and sediments of the Apies River, Gauteng, South Africa. AMB Express 2017, 7, 1-10. [CrossRef] [PubMed]

54. Griesel, M.; Jagals, P. Faecal indicator organisms in the Renoster Spruit system of the Modder-Riet River catchment and implications for human users of the water. Water SA 2002, 28, 227-234. [CrossRef]

55. Potgieter, N.; Karambwe, S.; Mudau, L.S.; Barnard, T.; Traore, A. Human Enteric Pathogens in Eight Rivers Used as Rural Household Drinking Water Sources in the Northern Region of South Africa. Int. J. Environ. Res. Public Health 2020, 17, 2079. [CrossRef]

56. Mbanga, J.; Abia, A.L.K.; Amoako, D.G.; Essack, S.Y. Longitudinal Surveillance of Antibiotic Resistance in Escherichia coli and Enterococcus spp. from a Wastewater Treatment Plant and Its Associated Waters in KwaZulu-Natal, South Africa. Microb. Drug Resist. 2021. [CrossRef]

57. Sahu, P.; Sikdar, P.K. Hydrochemical framework of the aquifer in and around East Kolkata Wetlands, West Bengal, India. Environ. Earth Sci. 2008, 55, 823-835. [CrossRef]

58. EPA (Environmental Protection Agency). SPECIATE 4.4 Database. Available online: https:/ / www.epa.gov / (accessed on 1 June 2015). 
59. Ahmad, N.; Jaafar, M.S.; Alsaffar, M.S. Study of radon concentration and toxic elements in drinking and irrigated water and its implications in Sungai Petani, Kedah, Malaysia. J. Radiat. Res. Appl. Sci. 2015, 8, 294-299. [CrossRef]

60. Rajeshkumar, S.; Liu, Y.; Zhang, X.; Ravikumar, B.; Bai, G.; Li, X. Studies on seasonal pollution of heavy metals in water, sediment, fish and oyster from the Meiliang Bay of Taihu Lake in China. Chemosphere 2018, 191, 626-638. [CrossRef] [PubMed]

61. Asare-Donkor, N.K.; Boadu, T.A.; Adimado, A.A. Evaluation of groundwater and surface water quality and human risk assessment for trace metals in human settlements around the Bosomtwe Crater Lake in Ghana. SpringerPlus 2016, 5, 1812. [CrossRef] [PubMed]

62. Saha, N.; Rahman, M.S.; Ahmed, M.B.; Zhou, J.L.; Ngo, H.H.; Guo, W. Industrial metal pollution in water and probabilistic assessment of human health risk. J. Environ. Manag. 2017, 185, 70-78. [CrossRef] [PubMed]

63. Mannzhi, M.P.; Edokpayi, J.N.; Durowoju, O.S.; Gumbo, J.; Odiyo, J.O. Assessment of selected trace metals in fish feeds, pond water and edible muscles of Oreochromis mossambicus and the evaluation of human health risk associated with its consumption in Vhembe district of Limpopo Province, South Africa. Toxicol. Rep. 2021, 8, 705-717. [CrossRef]

64. Ikenaka, Y.; Nakayama, S.M.M.; Muzandu, K.; Choongo, K.; Teraoka, H.; Mizuno, N.; Ishizuka, M. Heavy metal contamination of soil and sediment in Zambia. Afr. J. Environ. Sci. Technol. 2010, 4, 729-739. 